\title{
Zoysiagrass Genotypes Differ in Susceptibility to the Bluegrass Billbug, Sphenophorus parvulus
}

\author{
Jack D. Fry ${ }^{1}$ \\ Department of Horticulture, Forestry, and Recreational Resources, Kansas \\ State University, 2021 Throckmorton Plant Science Center, Manhattan, KS \\ 66506
}

\author{
Raymond A. Cloyd \\ Department of Entomology, Kansas State University, 123 West Waters Hall, \\ Manhattan, KS 66506
}

Additional index words. damage, infestation, insect pest, turfgrass, Zoysia spp.

\begin{abstract}
Zoysiagrass, in general, has few insect pest problems but may suffer significant damage from infestations of the bluegrass billbug (Sphenophorus parvulus Gyllenhal). This study evaluated 'Meyer' and DALZ 0102 zoysiagrass (both Zoysia japonica Steud.) and 31 experimental zoysiagrass progeny, including reciprocal crosses between $Z$. japonica $\times Z$. matrella (L.) Merr. or crosses between 'Emerald' ( $Z$. japonica $\times Z$. pacifica Goudsw.) $\times Z$. japonica. These grasses were evaluated in adjacent experiments with 18 progeny in one and 13 in another. Plots were maintained under golf course fairway conditions and experienced natural infestations of the bluegrass billbug in 2009 and 2010 with larval damage primarily evident in June and continuing throughout the remainder of the growing season. 'Meyer' suffered the highest level of damage on each of six rating dates, ranging from $\mathbf{1 7 \%}$ to $\mathbf{3 8 \%}$ of the experimental plot area affected. Among the zoysiagrass progeny, damage ranged from $0 \%$ to $35 \%$ with most showing less than $15 \%$ damage. Overall, zoysiagrass progeny associated with reciprocal crosses of $Z$. japonica $\times$ $Z$. matrella or 'Emerald' $\times Z$. japonica were less susceptible to bluegrass billbug than 'Meyer'.
\end{abstract}

Zoysiagrass (Zoysia spp.) is a warmseason turfgrass used in home lawns and golf course fairways within the transition zone of turfgrass adaptation and in the southern United States (Fry and Huang, 2004). Cultivars of Z. matrella (L.) Merr., including 'Cavalier', 'Diamond', and 'Zorro' and the cultivar Emerald $(Z$. japonica $\times Z$. pacifica Goudsw.) are recognized for their high quality; however, they lack freeze tolerance, whereas cultivars of $Z$. japonica (Steud.) have better freeze tolerance but are generally coarser in texture and lack the quality of $Z$. matrella cultivars and 'Emerald' (Fry and Huang, 2004). Since 2004, researchers at Kansas State University (Manhattan, KS) and Texas AgriLife Research-Dallas (Dallas, TX) have evaluated zoysiagrass progeny associated with reciprocal crosses between

\footnotetext{
Received for publication 27 May 2011. Accepted for publication 12 July 2011.

Thanks are extended to Drs. Dennis Genovesi, Milt Engelke, and Ambika Chandra at Texas A\&M AgriLife-Dallas for providing cultivars and progeny used in this experiment. We also thank the Heart of America Golf Course Superintendents Association, Kansas Golf Course Superintendents Association, and Kansas Turfgrass Foundation for partially funding this research.

Publication no. 11-373-J of the Kansas Agricultural Experiment Station.

${ }^{1}$ To whom reprint requests should be addressed; e-mail jfry@ksu.edu.
}

Z. japonica $\times$ Z. matrella or Z. japonica $\times$ 'Emerald' for quality characteristics and freeze tolerance. A significant number of these, including those we are reporting here, have demonstrated superior freeze tolerance compared with $Z$. matrella cultivars or 'Emerald' and have improved quality characteristics compared with $Z$. japonica cultivars including Meyer (Okeyo, 2010). Fortuitously, a natural infestation of the bluegrass billbug (Sphenophorus parvulus Gyllenhal) occurred in 2009 and 2010 in the experimental plots where these zoysiagrasses were being evaluated. As such, this allowed us to compare bluegrass billbug susceptibility of the new freeze-tolerant zoysiagrass progeny with 'Meyer'.

The bluegrass billbug is the most common insect pest of cool-season turfgrass including kentucky bluegrass (Poa pratensis L.) and perennial ryegrass (Lolium perenne L.). In addition, fine-leaf (Festuca spp.) and tall fescue (Festuca arundinacea Schreb) may be attacked (Hansen, 1987; Kindler and Spomer, 1986; Potter, 1998; Tashiro and Personius, 1970). Bluegrass billbug is native to North America and is present throughout most regions of the United States (Potter, 1998). Adults feed on and deposit eggs in crowns, leaf sheaths, and stems. Eggs hatch into young larvae that cause the most damage when tunneling into stems. Older larvae feed on roots and then pupate in the soil. Bluegrass billbug overwinters as an adult (Potter, 1998).
Studies have evaluated the resistance of cultivars and blends of kentucky bluegrass to the bluegrass billbug (Ahmad and Funk, 1982; Lindgren et al., 1981; Shearman et al., 1983). However, currently, there is minimal information associated with the presence of bluegrass billbug in Kansas and the susceptibility of zoysiagrass. Therefore, the objectives of this study were to monitor the presence of bluegrass billbug larvae at the Rocky Ford Turfgrass Research Center (Manhattan, KS) and determine the susceptibility of zoysiagrass progeny including reciprocal crosses between $Z$. japonica $\times Z$. matrella or between 'Emerald' $\times Z$. japonica to the bluegrass billbug.

\section{Materials and Methods}

Dr. Raymond A. Cloyd (Department of Entomology, Kansas State University, Manhattan, KS) identified all the bluegrass billbug larvae collected from the study area at the Rocky Ford Turfgrass Research Center (Manhattan, KS) during the course of the study. We evaluated 'Meyer' (Zoysia japonica), DALZ 0102 (experimental Z. japonica), and 31 zoysiagrass progeny resulting from crosses between 'Emerald' $\times Z$. japonica or reciprocal crosses between $Z$. matrella $\times$ $Z$. japonica for bluegrass billbug larval damage in separate, adjacent experiments. Zoysia matrella types included were 'Cavalier', DALZ 8501, or 'Diamond'. Zoysia japonica types included were 'Meyer', Chinese Common, or 'Zenith'. Parents of the progeny are presented in Tables 1 and 2. Families under a particular parental cross were assigned a prefix code (e.g., 5311 is 'Cavalier' $\times$ Chinese Common) and individual progeny were assigned numbers indicated after the hyphen (e.g., 5311-26).

Expt. 1 included 18 zoysiagrass progeny and Expt. 2 included 13 zoysiagrass progeny. Grasses were planted as 3-cm diameter plugs on $30-\mathrm{cm}$ centers in June 2007 into $1.5 \mathrm{~m} \times$ $1.5-\mathrm{m}$ plots at the Rocky Ford Turfgrass Research Center, Manhattan, KS. Plots were arranged in a randomized complete block design with three replicates per zoysiagrass progeny. The soil was a Chase silt loam (fine, montmorillonitic, mesic, Aquic, Argiudolls) with a $\mathrm{pH}$ of 7.8. The phosphorus level was $246 \mathrm{~kg} \cdot \mathrm{ha}^{-1}$ and potassium level was 950 $\mathrm{kg} \cdot \mathrm{ha}^{-1}$ before initiation of the study. Beginning in Sept. 2007, the experimental areas were maintained similar to golf course fairways. Plots were mowed to $1.3 \mathrm{~cm}$ in height 2 or $3 \mathrm{~d}$ weekly during the growing season using a reel mower with the clippings returned. In 2009 and 2010, in-ground irrigation was used 2 or $3 \mathrm{~d}$ weekly to supplement rainfall as needed so that $\approx 2.5 \mathrm{~cm}$ of water was received per week. Urea (46-0-0) was applied on 21 July and 19 Aug. 2009 and 20 July and 12 Aug. 2010 to provide nitrogen at $37 \mathrm{~kg} \cdot \mathrm{ha}^{-1}$.

Each plot was rated visually for percent bluegrass billbug larval damage three times in 2009 and 2010. Random monthly sampling across the experimental area confirmed the 
Table 1. Bluegrass billbug (Sphenophorus parvulus) larval damage on zoysiagrass progeny in Expt. 1 at the Rocky Ford Turfgrass Research Center (Manhattan, KS) in 2009 and 2010.

\begin{tabular}{|c|c|c|c|c|c|c|}
\hline \multirow[b]{3}{*}{ Progeny ${ }^{y}$} & \multicolumn{6}{|c|}{ Bluegrass billbug larval damage $(\%)^{z}$} \\
\hline & \multicolumn{3}{|c|}{2009} & \multicolumn{3}{|c|}{2010} \\
\hline & 6 July & 3 Aug. & 28 Aug. & 30 June & 15 July & $31 \mathrm{Ju}$ \\
\hline Cavalier $\times$ Meyer (5283-27) & $5.7 \mathrm{~cd}^{\mathrm{x}}$ & $6.7 \mathrm{bc}$ & $11.0 \mathrm{cde}$ & $3.3 \mathrm{~b}$ & $0.7 \mathrm{~b}$ & $2.0 \mathrm{~b}$ \\
\hline \multicolumn{7}{|l|}{ Cavalier $\times$ Chinese Common } \\
\hline $5311-3$ & $0.0 \mathrm{~d}$ & $0.0 \mathrm{c}$ & $0.0 \mathrm{e}$ & $0.0 \mathrm{~b}$ & $0.0 \mathrm{~b}$ & 0.0 \\
\hline $5311-8$ & $0.0 \mathrm{~d}$ & $0.0 \mathrm{c}$ & $3.3 \mathrm{de}$ & $1.0 \mathrm{~b}$ & $0.7 \mathrm{~b}$ & 0.0 \\
\hline $5311-22$ & $2.3 \mathrm{~cd}$ & $0.0 \mathrm{c}$ & $0.0 \mathrm{e}$ & $1.3 \mathrm{~b}$ & $0.0 \mathrm{~b}$ & 0.0 \\
\hline $5311-26$ & $15.0 \mathrm{bc}$ & $12.3 \mathrm{bc}$ & $15.0 \mathrm{bc}$ & $8.3 \mathrm{ab}$ & $1.0 \mathrm{~b}$ & 0.0 \\
\hline $5311-27$ & $11.7 \mathrm{bcd}$ & $10.0 \mathrm{bc}$ & $10.0 \mathrm{cde}$ & $5.7 \mathrm{~b}$ & $1.3 \mathrm{~b}$ & 0.01 \\
\hline $5311-32$ & $8.3 \mathrm{~cd}$ & $3.3 \mathrm{c}$ & 6.7 cde & $2.0 \mathrm{~b}$ & $0.0 \mathrm{~b}$ & 0.0 \\
\hline \multicolumn{7}{|l|}{ Zorro $\times$ Chinese Common } \\
\hline $5312-36$ & $1.7 \mathrm{~d}$ & $0.0 \mathrm{c}$ & $0.0 \mathrm{e}$ & $0.7 \mathrm{~b}$ & $0.0 \mathrm{~b}$ & 0.0 \\
\hline $5312-49$ & $1.7 \mathrm{~d}$ & $3.3 \mathrm{c}$ & $3.3 \mathrm{de}$ & $0.0 \mathrm{~b}$ & $1.0 \mathrm{~b}$ & 0.01 \\
\hline \multicolumn{7}{|l|}{ Emerald $\times$ Meyer } \\
\hline $5321-3$ & $1.7 \mathrm{~d}$ & $2.0 \mathrm{c}$ & $6.0 \mathrm{cde}$ & $0.7 \mathrm{~b}$ & $0.0 \mathrm{~b}$ & 0.7 \\
\hline $5321-24$ & $8.3 \mathrm{~cd}$ & $8.7 \mathrm{bc}$ & 7.3 cde & $0.0 \mathrm{~b}$ & $0.0 \mathrm{~b}$ & 0.7 \\
\hline $5321-45$ & $0.0 \mathrm{~d}$ & $1.3 \mathrm{c}$ & $3.3 \mathrm{de}$ & $0.0 \mathrm{~b}$ & $0.0 \mathrm{~b}$ & $0.0 \mathrm{~b}$ \\
\hline $5321-48$ & $21.7 \mathrm{~b}$ & $16.7 \mathrm{~b}$ & $15.0 \mathrm{bc}$ & $15.0 \mathrm{a}$ & $18.3 \mathrm{a}$ & 15.3 \\
\hline \multicolumn{7}{|l|}{ DALZ $8501 \times$ Meyer } \\
\hline $5324-18$ & $10.0 \mathrm{bcd}$ & $5.3 \mathrm{bc}$ & $2.0 \mathrm{de}$ & $4.3 \mathrm{~b}$ & $1.0 \mathrm{~b}$ & $0.0 \mathrm{~b}$ \\
\hline $5324-27$ & $1.7 \mathrm{~d}$ & $6.7 \mathrm{bc}$ & $12.0 \mathrm{~cd}$ & $0.3 \mathrm{~b}$ & $0.0 \mathrm{~b}$ & $0.0 \mathrm{~b}$ \\
\hline $5324-52$ & $11.7 \mathrm{bcd}$ & $2.0 \mathrm{c}$ & 5.3 cde & $1.3 \mathrm{~b}$ & $3.3 \mathrm{~b}$ & $4.0 \mathrm{~b}$ \\
\hline $5324-53$ & $3.3 \mathrm{~cd}$ & $3.3 \mathrm{c}$ & 5.0 cde & $1.7 \mathrm{~b}$ & $0.3 \mathrm{~b}$ & $0.0 \mathrm{~b}$ \\
\hline Meyer $\times$ Diamond $(5327-19)$ & $35.0 \mathrm{a}$ & $33.3 \mathrm{a}$ & $28.3 \mathrm{a}$ & $16.7 \mathrm{a}$ & $13.3 \mathrm{a}$ & $6.0 \mathrm{~b}$ \\
\hline DALZ 0102 & $0.0 \mathrm{~d}$ & $0.0 \mathrm{c}$ & $0.0 \mathrm{e}$ & $0.0 \mathrm{~b}$ & $0.0 \mathrm{~b}$ & $0.0 \mathrm{~b}$ \\
\hline Meyer & $35.0 \mathrm{a}$ & $35.0 \mathrm{a}$ & $25.0 \mathrm{ab}$ & $16.7 \mathrm{a}$ & $19.3 \mathrm{a}$ & $18.3 \mathrm{a}$ \\
\hline
\end{tabular}

zBluegrass billbug larval damage was rated visually on a $0 \%$ to $100 \%$ scale $(0 \%=$ no damage, $100 \%=$ complete damage).

yParents: 'Cavalier', 'Zorro', DALZ 8501, and 'Diamond' are Z. matrella types; Chinese Common, 'Meyer', and DALZ 0102 are Z. japonica types. 'Emerald' is Z. japonica $\times$ Z. pacifica.

${ }^{x}$ Means in a column followed by the same letter are not significantly different $(P \leq 0.05)$ using Fisher's least significant difference test.

Table 2. Bluegrass billbug (Sphenophorus parvulus) larval damage on zoysiagrass progeny in Expt. 2 at the Rocky Ford Turfgrass Research Center (Manhattan, KS) in 2009 and 2010.

\begin{tabular}{|c|c|c|c|c|c|c|}
\hline \multirow[b]{3}{*}{$\underline{\text { Progeny }}^{\mathrm{y}}$} & \multicolumn{6}{|c|}{ Bluegrass billbug larval damage $(\%)^{z}$} \\
\hline & \multicolumn{3}{|c|}{2009} & \multicolumn{3}{|c|}{2010} \\
\hline & 6 July & 3 Aug. & 28 Aug. & 30 June & 15 July & 31 July \\
\hline Cavalier $\times$ Chinese Common (5311-16) & $0.0 \mathrm{~b}^{\mathrm{x}}$ & $0.0 \mathrm{c}$ & 0.7 & $1.3 \mathrm{c}$ & $4.7 \mathrm{bc}$ & 3.3 \\
\hline Zorro $\times$ Chinese Common (5312-55) & $0.0 \mathrm{~b}$ & $0.7 \mathrm{c}$ & 0.7 & $0.0 \mathrm{c}$ & $0.0 \mathrm{c}$ & 0.0 \\
\hline \multicolumn{7}{|l|}{ Zorro $\times$ Meyer } \\
\hline $5313-23$ & $0.0 \mathrm{~b}$ & $2.0 \mathrm{c}$ & 0.7 & $0.0 \mathrm{c}$ & $0.0 \mathrm{c}$ & 0.0 \\
\hline $5313-34$ & $15.0 \mathrm{a}$ & $20.0 \mathrm{a}$ & 19.0 & $0.0 \mathrm{c}$ & $6.7 \mathrm{bc}$ & 4.7 \\
\hline $5313-71$ & $3.3 \mathrm{~b}$ & $3.3 \mathrm{bc}$ & 6.7 & $0.0 \mathrm{c}$ & $0.0 \mathrm{c}$ & 0.0 \\
\hline $5313-46$ & $0.3 \mathrm{~b}$ & $0.0 \mathrm{c}$ & 3.3 & $0.0 \mathrm{c}$ & $5.0 \mathrm{bc}$ & 5.0 \\
\hline \multicolumn{7}{|l|}{ Emerald $\times$ Meyer } \\
\hline $5321-9$ & $15.0 \mathrm{a}$ & $11.7 \mathrm{ab}$ & 19.0 & $18.3 \mathrm{~b}$ & $16.7 \mathrm{ab}$ & 8.0 \\
\hline $5321-18$ & $20.0 \mathrm{a}$ & $20.0 \mathrm{a}$ & 19.3 & $7.0 \mathrm{bc}$ & $10.7 \mathrm{bc}$ & 12.7 \\
\hline \multicolumn{7}{|l|}{ DALZ $8501 \times$ Meyer } \\
\hline $5324-26$ & $1.7 \mathrm{~b}$ & $0.0 \mathrm{c}$ & 16.7 & $5.0 \mathrm{c}$ & $8.0 \mathrm{bc}$ & 6.7 \\
\hline $5324-32$ & $3.3 \mathrm{~b}$ & $1.7 \mathrm{c}$ & 9.3 & $1.7 \mathrm{c}$ & $0.0 \mathrm{c}$ & 0.0 \\
\hline Meyer $\times$ DALZ 8508 (5325-11) & $1.7 \mathrm{~b}$ & $0.0 \mathrm{c}$ & 2.7 & $0.3 \mathrm{c}$ & $0.0 \mathrm{c}$ & 0.7 \\
\hline Meyer × Diamond (5327-67) & $0.0 \mathrm{~b}$ & $0.0 \mathrm{c}$ & 3.3 & $0.0 \mathrm{c}$ & $0.0 \mathrm{c}$ & 0.0 \\
\hline Emerald $\times$ Zenith $(5334-59)$ & $3.3 \mathrm{~b}$ & $5.3 \mathrm{bc}$ & 6.3 & $0.0 \mathrm{c}$ & $6.7 \mathrm{bc}$ & 1.7 \\
\hline DALZ 0102 & $0.0 \mathrm{~b}$ & $0.0 \mathrm{c}$ & 4.7 & $0.0 \mathrm{c}$ & $0.0 \mathrm{c}$ & 0.0 \\
\hline Meyer & $18.3 \mathrm{a}$ & $18.3 \mathrm{a}$ & 21.3 & $30.0 \mathrm{a}$ & $38.3 \mathrm{a}$ & 21.3 \\
\hline
\end{tabular}

${ }^{\mathrm{z} B}$ luegrass billbug larval damage was rated visually on a $0 \%$ to $100 \%$ scale $(0 \%=$ no damage, $100 \%=$ complete damage).

'Parents 'Cavalier', 'Zorro', DALZ 8501, DALZ 8508, and 'Diamond' are Z. matrella types; Chinese Common, 'Meyer', and DALZ 0102 are Z. japonica types; 'Emerald' is Z. japonica $\times Z$. pacifica.

${ }^{\mathrm{x}}$ Means in a column followed by the same letter are not significantly different $(P \leq 0.05)$ using Fisher's least significant difference test. There were no significant differences on 28 Aug. 2009 and 31 July 2010 .

presence of bluegrass billbug larvae in June and July of each year.

All percentage data associated with bluegrass billbug damage on the zoysiagrass cultivars and progeny were subject to arcsin square root transformation before analysis.

\section{Results and Discussion}

The bluegrass billbug has been reported in other Midwestern states, including Nebraska (Kindler and Spomer, 1986), and was revealed in the 1960s to be a turfgrass pest in Kansas (U.S. Department of Agriculture, Plant Pest Control Division, 1964-1968). However, this study is the first to report that bluegrass billbug is present in east-central Kansas and will attack zoysiagrass. 'Meyer' was consistently among those grasses exhibiting the highest levels of bluegrass billbug larval damage (Fig. 1) with ratings ranging from $16.7 \%$ to $38.3 \%$ (Tables 1 and 2). In Expt. 1, on 6 July and 3 Aug. 2009, only progeny from 'Meyer' $\times$ 'Diamond' (5327-19) had a level of damage similar to 'Meyer' (Table 1). Grasses exhibiting bluegrass billbug larval damage on one or more rating dates in 2009 included 5311-26 ('Cavalier' $\times$ 'Meyer'), 5321-48 ('Emerald' $\times$ 'Meyer'), and 5324-27 (DALZ $8501 \times$ 'Meyer'). Bluegrass billbug damage in 2010 was substantially lower than in 2009 ( $0 \%$ to $19 \%)$, but 'Meyer,' 5321-48 and 5327-19 experienced greater than $15 \%$ damage on one or more rating dates.

In Expt. 2, differences among grasses associated with bluegrass billbug damage occurred on the first two rating dates of each year (Table 2). Progeny from 'Emerald' $x$ 'Meyer' (5321-9 and 5321-18) and 'Zorro' $x$ 'Meyer' (5313-34) were similar to 'Meyer' on the first two rating dates. In 2010, 'Meyer' had the highest bluegrass billbug larval damage on each date. The only other progeny that had a higher level of damage compared with those experiencing no damage was 5321-9 ('Emerald' $\times$ 'Meyer'). Reinert et al. (2010) showed that 'Meyer' was the most susceptible zoysiagrass cultivar to larval feeding by another billbug species, the hunting billbug, Sphenophorus venatus vestitus Chittenden. Furthermore, they demonstrated that cultivars of $Z$. matrella including 'Diamond', 'Zorro', and 'Cavalier', which were included in the crosses used in the current study, were more tolerant than $Z$. japonica cultivars to hunting billbug larval feeding.

In conclusion, bluegrass billbug is present in east-central Kansas although sometimes sporadically; however, this insect pest will feed on and is capable of causing damage to certain cultivars/progeny of zoysiagrass. In particular, 'Meyer' is quite susceptible to bluegrass billbug injury, and it is the most widely used cultivar in the transition zone. As such, monitoring for and management of bluegrass billbug larvae may be warranted when maintaining 'Meyer' zoysiagrass. Many of the experimental zoysiagrasses evaluated exhibited excellent resistance (or were less susceptible) to bluegrass billbug larvae and have also been shown to exhibit freeze tolerance comparable to 'Meyer' and turf quality characteristics superior to Meyer (Okeyo, 2010). Future releases of a zoysiagrass with these attributes will be useful to turfgrass practitioners. 


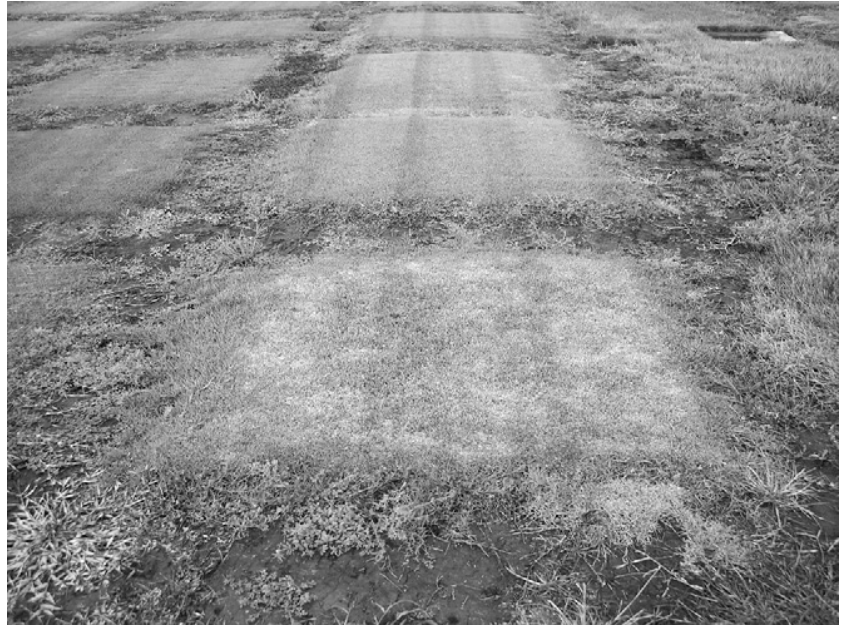

Fig. 1. 'Meyer' zoysiagrass (foreground) displaying larval damage from the bluegrass billbug, Sphenophorus parvulus, whereas some experimental progeny (background) were not damaged and may be less susceptible.

\section{Literature Cited}

Ahmad, S. and C.R. Funk. 1982. Susceptibility of kentucky bluegrass cultivars and selections to infestations of and injury by the bluegrass billbug (Coleoptera: Curculionidae). New York Entomol. Sci. 90:31-34.
Fry, J. and B. Huang. 2004. Applied turfgrass science and physiology. John Wiley and Sons, Hoboken, NJ.

Hansen, J.D. 1987. Seasonal history of bluegrass billbug, Sphenophorus parvulus (Coleoptera: Curculionidae), in a range grass nursery. Environ. Entomol. 16:752-756.
Kindler, S.D. and S.M. Spomer. 1986. Observations on the biology of the bluegrass billbug, Sphenophorus parvulus Gyllenhal (Coleoptera: Curculionidae) in an eastern Nebraska sod field. J. Kans. Entomol. Soc. 59:26-31.

Lindgren, D.T., R.C. Sherman, A.H. Bruneau, and D.M. Schaaf. 1981. Kentucky bluegrass cultivar response to bluegrass billbug, Sphenophorus parvulus Gyllenhal. HortScience 16:339.

Okeyo, D. 2010. Growth characteristics and freezing tolerance of zoysiagrass cultivars and experimental progeny. PhD diss., Dept. of Horticulture, Forestry, and Recreation Resources, Kansas State Univ.

Potter, D.A. 1998. Destructive turfgrass insects: Biology, diagnosis, and control. Ann Arbor Press, Chelsea, MI.

Reinert, J.A., M.C. Engelke, and J.J. Heitholt. 2010. Hunting billbug resistance among zoysiagrass cultivars. USGA Turfgrass and Environmental Research Online 9:1-11.

SAS Institute, Inc. 2003. SAS/STAT user's guide. SAS Inst., Inc., Cary, NC.

Shearman, R.C., D.M. Bishop, D.H. Stiengger, and A.H. Bruneau. 1983. Kentucky bluegrass cultivar and blend response to bluegrass billbug. HortScience 18:441-442.

Tashiro, H. and K.E. Personius. 1970. Current status of the bluegrass billbug and its control in western New York home lawns. J. Econ. Entomol. 63:23-29.

U.S. Department of Agriculture, Plant Pest Control Division. 1964-1968. Coop. Econ. Insect Rep. 14(31) and 14(37):870, 878. 